\title{
Dedication to Dr. Robert Murray
}

(1916-1998)

The editors would like to dedicate this issue on the Health Effects of Silica to the memory of Dr. Robert Murray who sadly died last year. Bob Murray was one of the great figures of twentieth century occupational medicine and a former president of ICOH. He attended the conference on which this issue is based and had hoped to write an introductory preface for this issue. Unfortunately, this was not to be. He was a man who impressed all those who met him by his humanity, his culture and his erudition all mixed with a great sense of fun. He is missed.

\section{KARGER}

Fax + 41613061234

E-Mail karger@karger.ch

www. karger.com (c) 1999 S. Karger AG, Basel

1420-326X/99/0082-0113\$17.50/0

Accessible online at:

http://BioMedNet.com/karger 